\title{
Jon A. Shields, The Democratic Virtues of the Christian Right
}

\author{
Princeton, NJ: Princeton University Press, 2009. 198 pp. \$29.95. ISBN-10: 0691137404; \\ ISBN-13: 978-0691137407
}

\author{
Andrew Sabl
}

Published online: 12 February 2010

(C) The Author(s) 2009. This article is published with open access at Springerlink.com

This is not a conformist book. Its thesis is bold: that political theorists and mainstream commentators have been looking for democracy in all the wrong places. The New Left's call for a reinvigorated, participatory democracy aligned "around contentious moral questions that animate citizens rather than bureaucratic, technical, or economic issues that tend to bewilder and subdue them" has been answered. But participation's harbingers stand not on the left but on the Christian Right, in particular the pro-life movement (Shields' main focus). Politics was once criticized as an elite, expert game that failed to involve ordinary citizens; the new politics of moral issues has ended that. Conservative evangelicals, once the least involved portion of the electorate, are now among the most involved. They are also, Shields claims, among the most deliberative - if we gloss deliberative values as we should. Such values, Shields argues, should be defined as "the norms of behavior that collectively make public deliberation possible." Shields finds that Christian Right activists advocate, and inculcate in rank-and-file members through advocacy, training, and discipline, four such norms: "the practice of civility and respect," "the cultivation of real dialogue by listening and asking questions," "the rejection of appeals to theology," and "the practice of careful moral reasoning."

The one alleged deliberative norm that the Christian Right rejects- - "openness to alternative points of view"-is one that Shields believes we all should reject as inconsistent with justice-based social movements. Christian leaders "do not encourage activists to question their own convictions."

A. Sabl $(\square)$

UCLA Department of Public Policy,

3250 School of Public Affairs Building,

Los Angeles, CA 90095-1656, USA

e-mail: sabl@ucla.edu
But Shields thinks this is a good thing. "Strong moral convictions," not "moral skepticism," give movements courage and purpose: no one regrets the moral confidence of abolitionists or freedom riders. Shields calls for "deliberative partisans" (his coinage, and his emphasis) who may use the Socratic method as a tool of persuasion but reject the Socratic goal of ceaseless self-questioning. Such partisans benefit society by putting forth their own views with "devotion and intellectual seriousness," confident that the merit of any claim will bear on its success.

This book challenges political theorists to engage "the empirical realities of political life," especially the reality of necessary tradeoffs. Skeptical and nonpartisan citizens will not be easily mobilized to pursue civic goods; greater participation will come at the cost of some "excesses." Shields' book also challenges students of social movements to broaden the criteria used to assess such movements. What should count is not just a movement's "success," and certainly not its substantive ends - whose moral goodness social scientists are in no position to assess - but its ability to engage citizens and improve the quality of public debate. Christopher Lasch's epigram, based on Hannah Arendt's categories, could serve as Shields' motto: "Action is to behavior what forgiveness is to tolerance."

Shields makes a remarkably strong case. Defending an unpopular thesis requires methodological thoroughness and sharp argument. Shields displays both. As to methods, those employed here are both wide and deep, combining voting data with analyses of movement literature and - crucially - participant observation in a variety of pro-life groups that operate in different settings. Added to Shields' unusual, self-abnegating approach to sociology - he studies moral groups more to understand than to explain them, and rejects the ubiquitous assumption that moral conflicts reflect "culture" or social forces - this gives Shields the ability to see new phenomena and avoid old assumptions. To take a prominent case: while 
Shields mostly avoids polemic, he singles out Kristen Luker's Abortion and the Politics of Motherhood for particular criticism. Her flaws are both methodological (small and narrow samples, exclusively of activists) and conceptual (an unjustified reduction of moral principles to worries over "motherhood"). Luker's work has been widely praised, often regarded as path-breaking. But it comes out of Shields' book badly, perhaps critically, wounded.

A few of Shields' findings confirm (with good data) what intelligent amateurs already knew, or thought they knew. Media darlings like Jerry Falwell and Randall Terry, far from being representative of the Christian Right, are indeed widely despised as extreme, embarrassing, and theologically narrow; pro-life advocates indeed use logical arguments and do not merely parrot scripture or religious authority. (The latter finding may, however, be news to some theorists of deliberative democracy who don't get out much. One fairly famous representative of that school asserted in public and in my hearing that our democracy was threatened by those prone to end debate with "because the Pope said so.")

But most of what the book reports is striking and far from obvious. For instance, Shields finds that religious Right activists have the same problem Left activists have of overestimating their similarity to ordinary citizens - but the Right, unlike the Left, knows this, and has responded by training their activists to know what is "normal" and to compensate for the fact that they aren't. And Shields demonstrates fairly conclusively that reputable Christian Right groups make huge efforts to train advocates in civility, not just for pragmatic reasons but because scripture demands humility and charity. (This, I infer, is why Shields uses "Christian Right" rather than "religious Right." He believes the specifics of Christianity matter, affecting distinctly how movements act, and therefore stresses those specifics rather than eliding them).

Most fascinating, Shields argues that "Christian Right elites...tend to agree with Gutmann and Thompson [leading theorists of "deliberative democracy"]. Like other Christian movements in American history, the Christian Right has learned that religious arguments are unpersuasive to many of their fellow citizens. Thus, Christian leaders tell their rankand-file activists to carefully avoid religious arguments in public forms.... It is actually the secular pro-choice movement that routinely frames abortion as a religious issue." Christian activists are taught to speak to non-Christians of "injustice," not "sin," and to stress how the "civil liberties of the unborn" transcend theological boundaries. In private, they speak of $\sin$ more freely, but still try, sincerely, to love pro-choice sinners. The book could be encapsulated in a prayer Shields witnesses outside an abortion clinic: "We know that these escorts believe that they are doing the right thing and are good people. But please Lord soften their hearts so that they will turn away from baby-killing." Shields calls this "both conciliatory and judgmental," intending praise on both counts.
On the level of argument, Shields also adduces original insights (rare birds), not all of them fully proven but almost all intriguing. He claims that the value of personal authenticity and personal empowerment prized by the New Left, but not the activist Right, makes civil discourse impossible: civility requires, as Richard Sennett argued, public masks. And he argues effectively that many liberals and left-liberals have become fair-weather advocates of participation. They were happy to praise the antiwar and civil rights movements, but the success of the moral Right provokes calls for end-of-ideology centrism and the virtues of the non-activist "median voter" (who sounds, Shields grins, like the "silent majority")—not that the median voter would support Roe $v$. Wade if she had any idea how few abortion restrictions it allows. This book will be dismissed by many liberals and all radicals, but that is a shame. It should justly provoke in both serious anxieties, and new ones.

In spite of its quality and daring, Shields' work is vulnerable to many small criticisms and two more basic objections. Take the smaller faults first. Regarding voting behavior, not his specialty, Shields argues that conservative evangelicals, alienated ticket-splitters in 1972, were energized and brought back to civic life by moral issues. He ignores an obvious and much-studied alternative theory: that these ticket-splitting conservative evangelicals were Southern Democrats dissatisfied by national Democrats' racial liberalism but later enlisted by the Republican party through racial appeals. Shields' assumption that contemporary liberals-Shields prefers "the Left," which is more partisan - care deeply about New Left values, and would be disturbed to find the other side embodying them, might be questioned. In my experience, most liberals under fifty are either ignorant of the New Left or embarrassed by it.

Finally, there is the matter of George Tiller. Shields argues that the violent fringe of the pro-life movement is fading; crimes against both persons and property are way down, and no murders have occurred for some time. A few weeks after the book came out, Dr. Tiller was murdered in church. The murder is not Shields' fault, and the statistical trends remain what they are. But given the vicious and constant threats Tiller faced, Shields might have been more scrupulous in his fact checking. He attributes some shocking claims about Tiller's practice to "the website of Dr. Tiller," when the web address he cites is that of a site that is bitterly opposed to Tiller and that highlights quotations from Tiller flagrantly out of context. (The website is still up, apparently unchanged, as of this writing, and archived by me if that changes).

The bigger criticisms concern bigger matters: reason and liberty. Shields' view of human reason is, put simply, narrow. He repeatedly (though in passing, since his methodology suggests he should steer clear) opposes arguments grounded in the natural law tradition to "relativism," "postmodernism," or "skepticism," or cites postmodern works as the only alternative to his own perspective, as if these exhausted the 
possibilities. We must choose between natural law or the abyss. This is consistent with Shields' view that the pro-life movement should love its opponents but may legitimately remain deaf to their arguments. These arguments, by implication, may be expressive but cannot be rational.

Contrast this with Alasdair MacIntyre, himself a Thomist of a reflective stamp, who in After Virtue used the abortion debate as one example of an argument that was "interminable" because the various parties occupied incompatible moral traditions. Thomist reasoning indeed suggests abortion's grave injustice because embryos are human beings who have all adult capacities in immature form; Kantian reasoning (which, one could add, denies the coherence of Thomist categories like substance and ontology) uses a universalizing argument to conclude that abortion may be wrong but no more wrong than contraception; Lockean reasoning derives a right to abortion from women's inviolable rights over their persons, including their bodies. MacIntyre, too, ends up claiming our real choice is "Aristotle or Nietzsche"-but he admits along the way that other forms of reason are reason, and make perfect sense, within their own traditions.

Shields' confidence that reason speaks in one voice is particularly dangerous given the minority status of his preferred conception of it. As I have previously argued, some would say mocked ("Blastocyst Rights-What Science?" Society 44, No. 4 [May/June 2007]: 38-42.), if one adopts the perspective of Kant's or Locke's epistemology, or that of modern science generally, it is Thomist talk of "ontology" and "substance" that contains no reasons at all. (This dismissal applies only to blastocysts. While late-term fetuses may or may not count as human beings, no epistemology rules it out.) Given that Shields refers to science and civil liberties as common languages suitable for respectful debate, he surprisingly fails to stick to such languages. Most likely, Shields sees no difference between the language of natural law or ontology and that of rights, civil liberties, and injustice: he believes the former, like the latter, to be common ground that all rational citizens must share. If so, he is mistaken, and in making this mistake perhaps reveals that Sennett's masks sometimes slip.

It is the Lockean tradition that is most neglected by this book. Shields slights questions of rights and governmental power consistently, in fact deliberately; he claims that rights are a Left concern, while the Right prefers to focus on "moral obligation." One would hardly know from the book, with its focus on loving efforts to change hearts and minds, that the pro-life movement proposes a ban on abortion, enforced through the criminal law. (The word "illegal" appears twice in the book; one of those times, it precedes "immigrants.") For rights-based supporters of abortion rights, this fact is not peripheral but central: women's control over their bodies is the main issue implicated not only by legal bans on abortion but by moral demands that women defer to others who argue from moral premises that they themselves reject.
Taking Lockeanism seriously—broadly understood; Locke's specific arguments are optional—would illuminate some omissions in Shields' argument. Shields assumes throughout that the question of whether fetuses are human settles the question of abortion. He mentions in passing Judith Jarvis Thomson's argument (think back to college; she imagines one of us strapped to an ailing violinist for nine months) that a personal right of movement or bodily control might justify abandoning even human life. But he lays aside the argument quickly, on the grounds that the pro-choice movement has not adopted Thomson's argument (which, Shields claims, concedes that "the embryo is a person"; I would say it only does so hypothetically). This is true only if we take things very literally. While few movement activists are likely to take as a manifesto an intricate article from Philosophy and Public Affairs, slogans such as "a woman has a right to control her body" or "who decides: you or them?" are long-standing and successful versions of the Thomson argument, which in turn resembles a Lockean argument, in folk form. One will think these slogans beside the point if one assumes at the outset that rights are a distraction from the real issue, namely life. But the slogans have been successful - they were tested firstbecause many Americans regard them as central, not distracting. Their appeal extends beyond those who endorse appeals to self-ownership as such. Anyone who defends abortion as a matter of personal right- "privacy" being the right word for the moral value here, whether or not it names something in the Constitution-is likely to think that the boundaries of personal decision must be addressed before, not after, moral duties are asserted at the point of shield and gun. Any rights-based perspective must therefore question Shields' determination to separate good political practices from the ends their practitioners hope, coercively, to further.

These are, admittedly, engaged as well as scholarly criticisms. Only innovative and meaty work, the kind that might change minds, calls for such criticisms. Among other virtues, The Democratic Virtues of the Christian Right is both careful and clear enough to interest scholars and provocative and relevant enough to engage students with little background. This is both a courageous work and, in many ways, a classic. It deserves to start a great many arguments, and there is little doubt that it will.

Open Access This article is distributed under the terms of the Creative Commons Attribution Noncommercial License which permits any noncommercial use, distribution, and reproduction in any medium, provided the original author(s) and source are credited.

Andrew Sabl is Associate Professor of Public Policy and Political Science at UCLA. He is the author of Ruling Passions: Political Offices and Democratic Ethics (Princeton University Press, 2002) and many scholarly articles. He is currently completing a book on the political theory of David Hume's History of England. 